\title{
Development and evaluation of tractor operated plastic mulch laying equipment
}

SIDDESH MARIHONNAPPANAVARA AND M. VEERANGOUDA

Received : 06.05.2017; Revised : 03.08.2017; Accepted : 17.08 .2017

See end of the Paper for authors' affiliation

Correspondence to :

\section{SIDDESH}

MARIHONNAPPANAVARA

Department of Farm

Machinery and Power

Engineering, College of

Agricultural Engineering,

University of Agricultural

Sciences, RAICHUR

(KARNATAKA) INDIA

Email : siddeshgouda@gmail.

com
- ABSTRACT : A tractor operated plastic mulch laying equipment was developed to mechanize the conventional plastic mulching. A plastic mulch roller was mounted on the main frame of equipment and drip roll carrier assembly also mounted on main frame. The soil covering unit and press wheel assembly have been attached to it with the help of clamps. A $35 \mathrm{hp}$ tractor was used as a power unit for both plastic mulching and drip laying operation. Various parameters such as soil moisture content, draft, fuel consumption and soil temperature were measured. The average soil moisture of the plastic mulched beds was 19.20,19.30 and 19.20\% at forward speed of 2.0, 3.0 and $4.0 \mathrm{~km} \mathrm{~h}^{-1}$, respectively. The average values of draft were 3139,3193 and $3222 \mathrm{~N}$ at forward speed of $2.0,3.0$ and $4.0 \mathrm{~km} \mathrm{~h}^{-1}$, respectively.

- KEY WORDS : Plastic mulch roller units, Drip roll carrier assembly, Soil covering unit, Press wheel assembly

- HOW TO CITE THIS PAPER : Marihonnappanavara, Siddesh and Veerangouda, M. (2017). Development and evaluation of tractor operated plastic mulch laying equipment. Internat. J. Agric. Engg., 10(2) : 374-378, DOI: 10.15740/HAS/IJAE/10.2/374-378. 